\title{
Analysis of the Impact of Land Use Changes on Soil Erosion Intensity and Sediment Yield Using the IntErO Model in the Talar Watershed of Iran
}

\author{
Maziar Mohammadi ${ }^{1}$, Abdulvahed Khaledi Darvishan ${ }^{1, * \mathbb{D}}$, Velibor Spalevic ${ }^{2}$ (D) Branislav Dudic ${ }^{3,4, *(\mathbb{D})}$ \\ and Paolo Billi ${ }^{5}$ (D)
}

check for updates

Citation: Mohammadi, M.; Khaledi Darvishan, A.; Spalevic, V.; Dudic, B.; Billi, P. Analysis of the Impact of Land Use Changes on Soil Erosion Intensity and Sediment Yield Using the IntErO Model in the Talar Watershed of Iran. Water 2021, 13, 881. https://doi.org/ 10.3390/w13060881

Academic Editor: Dimitrios Myronidis, Sopan Patil and Milan Gocić

Received: 17 February 2021

Accepted: 19 March 2021

Published: 23 March 2021

Publisher's Note: MDPI stays neutral with regard to jurisdictional claims in published maps and institutional affiliations.

Copyright: (c) 2021 by the authors. Licensee MDPI, Basel, Switzerland. This article is an open access article distributed under the terms and conditions of the Creative Commons Attribution (CC BY) license (https:// creativecommons.org/licenses/by/ $4.0 /)$.
1 Department of Watershed Management Engineering, Faculty of Natural Resources, Tarbiat Modares University, Noor 46417-76489, Iran; maziarmohammadi68@yahoo.com

2 Department of Geography, Faculty of Philosophy, University of Montenegro, 81400 Niksic, Montenegro; velibor.spalevic@ucg.ac.me

3 Faculty of Management, Comenius University in Bratislava, 82005 Bratislava, Slovakia

4 Faculty of Economics and Engineering Management, University Business Academy, 21107 Novi Sad, Serbia

5 International Platform for Dryland Research and Education, Arid Land Research Center, Tottori University, Tottori 680-0001, Japan; bli@unife.it

* Correspondence: a.khaledi@modares.ac.ir (A.K.D.); branislav.dudic@fm.uniba.sk (B.D.); Tel.: +98-9183795477 (A.K.D.)

\begin{abstract}
Land use change is known as one of the main influencing factors on soil erosion and sediment production processes. The objective of the article is to study on how land use change impacts on soil erosion by using Intensity of Erosion and Outflow (IntErO) as a process-oriented soil erosion model. The study has been conducted under land use changes within the period of 1991-2014 in the Talar watershed located in northern Iran. The GIS environment was used to prepare the required maps including Digital Elevation Model (DEM), geology, land use, soil, and drainage network. The climatology data including average annual precipitation and air temperature as well as the volume of torrential rain were extracted from the data of meteorological stations located inside and around the study watershed. The results indicates that, within the period of 1991-2014, the forest area decreased by $12,478.04$ ha $(6 \%)$, while the other land uses including rainfed agriculture, rangeland, irrigated agriculture, and residential area increased by $7248.25,4481.05,476.00$, and 273.95 ha, respectively. The estimated outflow with 100 year return interval was $432.14 \mathrm{~m}^{3} \mathrm{~s}^{-1}$ in 1991 , which increased to $446.91 \mathrm{~m}^{3} \mathrm{~s}^{-1}$ in 2014 . It can be concluded that the probability of larger and/or more frequent floods waves in the Talar River is expected to increase. In addition, the amount of production of erosion material (gross erosion) in the watershed increased from 1,918,186 to $2,183,558 \mathrm{~m}^{3} \mathrm{yr}^{-1}$, and the real soil losses per year (sediment yield) of the watershed increased from $440,482.4$ to $501,421.3 \mathrm{~m}^{3} \mathrm{yr}^{-1}$. The results clearly emphasized how the lack of appropriate land management and planning leads to increase the maximum flow discharge and sediment yield of the watershed.
\end{abstract}

Keywords: land use changes; land management; erosion potential; Gavrilovic method; IntErO; sensitivity analysis; sediment yield; Iran

\section{Introduction}

Soil erosion is one of the most significant causes of land degradation and an important environmental hazard throughout the world, especially in developing countries [1]. Sediment yield and soil erosion are two main constraints on sustainable management of water resources and soil [2]. The quantification of these processes is crucial to design any scientifically based soil and water conservation plan and integrated land management $[3,4]$. The acceleration of soil erosion due to human activities on a global scale has led to an 
increased sediment flow in many parts of the world [5]. Unwanted complementary effects of soil erosion, such as loss of soil fertility, reduced water quality, alteration of the hydrological systems, and environmental contaminations, have been identified as a serious problem for human sustainability [6,7]. Land cover and land use changes are key factor in controlling the hydrological response of a watershed. Many studies have shown that there is a significant relationship between land use change and soil erosion [8,9]. Land use change may result in an increase of sediment and nutrient supply to rivers and may affect the water balance in the watershed and its variability, which must be assessed on a local scale [10]. Direct measurement of soil erosion in watersheds and water-sediment sampling is very time consuming and costly [11]. Therefore, the use of soil erosion and sediment yield models at watershed scale is globally raising the interest of specialists. The quantitative understanding of hydrological process at watershed scale also needs the modelling of microscale processes, such as infiltration, permeability and even water and particles transport processes in porous soils [12,13]. Many models, such as the Water Erosion Prediction Project (WEEP), Chemicals, Runoff, and Erosion from Agricultural Management Systems (CREAMS), European Soil Erosion Model (EuroSEM), and Soil and Water Assessment Tool (SWAT), have been developed with varying degrees of complexity in order to fulfil the growing request for a reliable and easy to manage tool to predict erosion and sediment yield. Examples of comparison between the Erosion potential method (EPM) and the Revised Universal Soil Loss Equation (RUSLE) is well presented in the research of Efthimiou et al. [14], and storm event interaction with sediment transport is presented in the research of Panagoulia et al. [15].

The main problem of the process-based models is the large number of input parameters and the lack of data to validate the model predictions [16]. Therefore, empirical models for soil erosion assessment play an important role in soil conservation planning [17]. The EPM is empirical model originally developed for Yugoslavia $[18,19]$ and used in many studies [20-25], especially to investigate the effect of land use on soil erosion and sediment yield [26,27]. Applicability of the EPM method in analyzing erosion potential using spatial data manipulation techniques (GIS environment) was first tested in the research of Globevnik et al. [28].

The Intensity of Erosion and Outflow (IntErO) of Spalevic [29] is a program package with the EPM integrated into the algorithm for Windows Operating System [11,30,31].

In some scenarios, climate projections indicate an increase in temperature of as much as $2{ }^{\circ} \mathrm{C}$ and a $20 \%$ decrease in daily precipitation. These predictions urge experts, especially in the Middle Eastern countries, to assess future changes in water distribution capacities in watersheds and to reconsider the management of reservoirs and dams. It is necessary to work in a broader context to develop adaptation strategies for the optimal use of the available water [11].

The main purpose of this study is the application of the IntErO model to evaluate the effects of land use changes for two periods (1991-2014) on soil erosion and sediment yield in Talar watershed in Iran. With this study we try to create one of the sustainable forms of modelling that would be calibrated and validated in the close region of the studied Talar catchment and afterwards used to evaluate how water resources can meet requirements in water for local community, eco sectors, and agricultural production.

\section{Materials and Methods}

\subsection{Study Area}

The Talar River Basin is located in northern Iran, in the Mazadaran Province, south of the Caspian Sea. Talar is a mountainous watershed with an area of $2055.75 \mathrm{~km}^{2}$ and subjected to a Mediterranean rainfall regime. The study area has an annual minimum and maximum temperature of 7.7 and $21.1^{\circ} \mathrm{C}$ and an average annual rainfall of $552.7 \mathrm{~mm}$, respectively [32]. The location of the Talar catchment is presented in Figure 1. In terms of lithology, the watershed is mostly covered by igneous, metamorphic, and sedimentary rocks [32]. The greatest amount of the geological units (about 61\%) consists of Mesozoic 
rocks. In the study area, 58 types of soil with different physical and chemical properties are present. A, B, and C hydrological soil groups cover $60,21,19 \%$ of the watershed, respectively, whereas the hydrological group $\mathrm{D}$ is not present. The average discharge measured at the Shirgah flow gauge in the 1971-1998 interval is $7.95 \mathrm{~m}^{3} \mathrm{~s}^{-1}$, whereas the highest discharge ever recorded is $93.46 \mathrm{~m}^{3} \mathrm{~s}^{-1}$. The most important land uses of the study area are forests, irrigated lands, rainfed agriculture, rangelands, and residential areas.

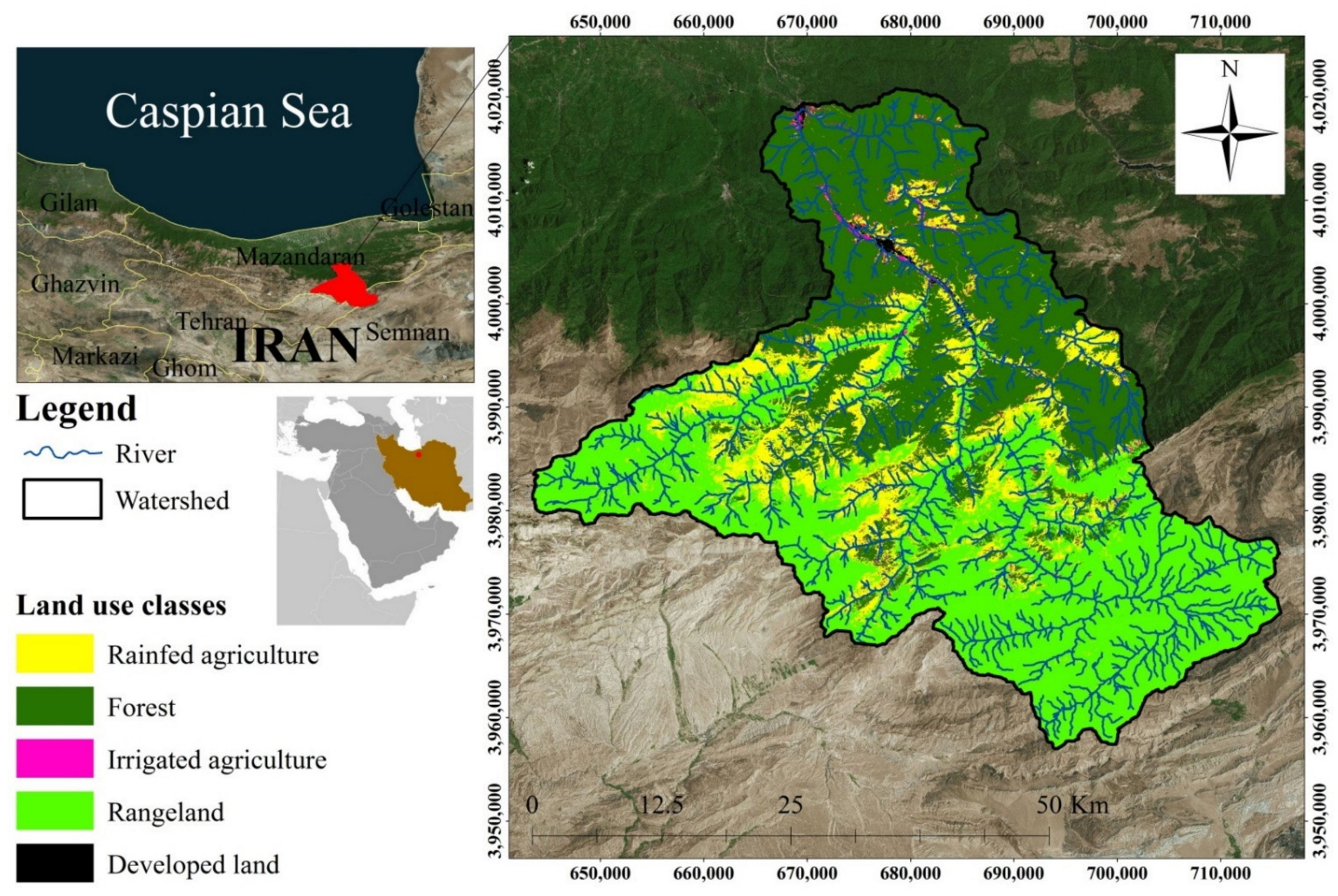

Figure 1. Position of the Talar River Basin, Mazadaran Province, North Iran.

\subsection{IntErO Model Application}

In Iran, the Intensity of Erosion and Outflow-IntErO program package of Spalevic [29], based on Erosion Potential Method-EPM of Gavrilovic [18,19], proved to return good predictions of runoff and soil erosion intensity, specifically in the Region of Shirindareh River basin, north-eastern Iran [21,33-37] as well as Khamsan Representative Watershed, western Iran [33]; Chamgardalan Watershed of Ilam Province, western Iran [38]. In this study the IntErO was used to obtain estimates of soil erosion intensity in the Talar river basin, Mazandaran Province, Iran.

The method has clearly defined procedures and subjective evaluations are reduced to a minimum [11,31].

The IntErO model, an upgrading of the Surface and Distance Measuring [39] and River Basins $[39,40]$ programs and can be used for handling a large number of data with the processing of 27 inputs, returning, after the calculations, 22 final result parameters [11]. The IntErO flowchart is presented in Figure 2.

The input data for the IntErO model processing are presented in Table 1 and Figure 3. 


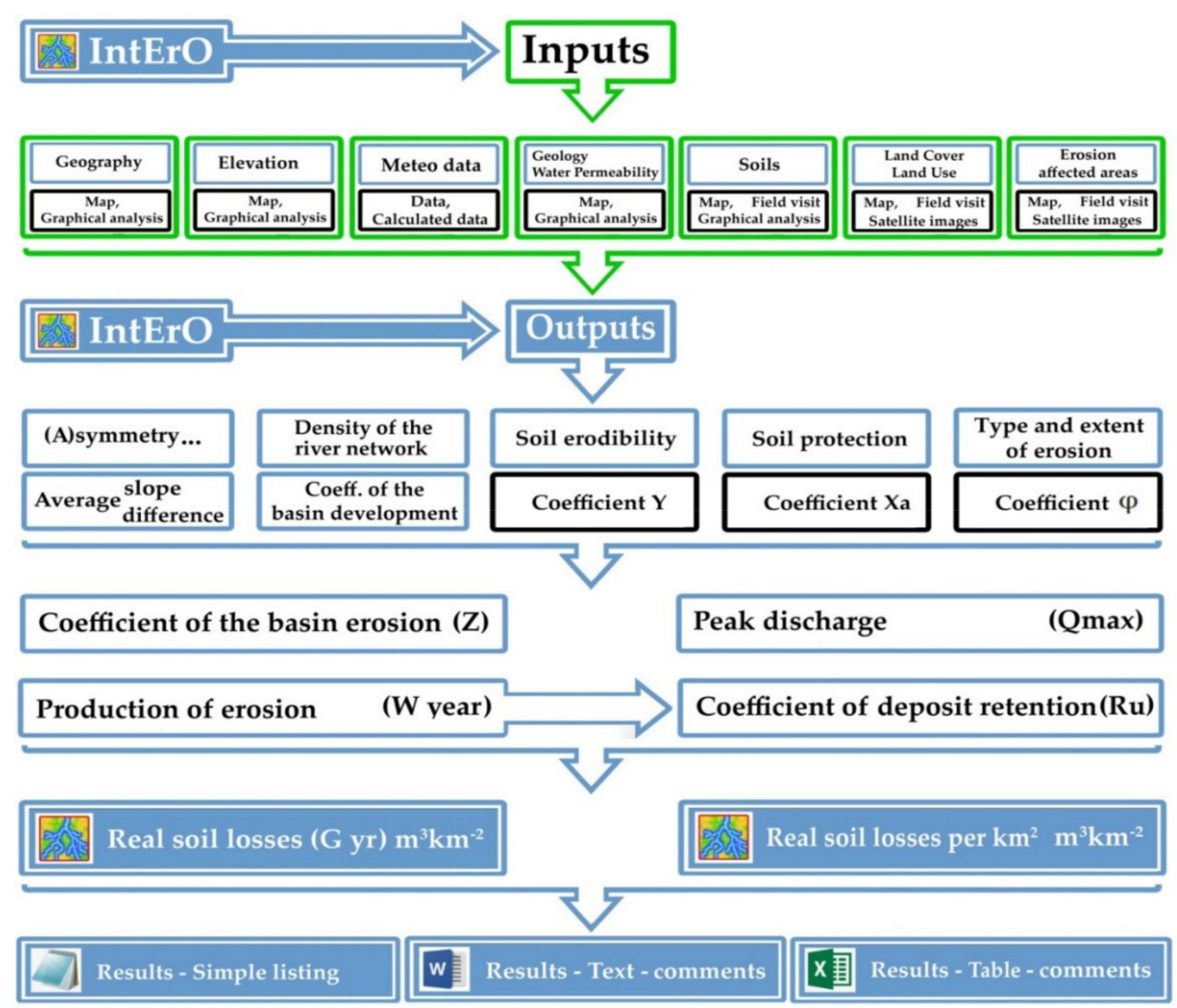

Figure 2. Flow chart of the Intensity of Erosion and Outflow (IntErO) model with the details on key inputs and outputs (revised, based on Spalevic et al. [11]).

Table 1. Input data for the IntErO in Talar watershed.

\section{Inputs}

River basin areas $(\mathrm{F})$

The length of the watershed $(\mathrm{O})$

The area of the bigger river basin part $(\mathrm{Fv})$

The area of the smaller river basin part (Fm)

Natural length of the main watercourse (Lv)

Length of the contours/isohyets (liz)

Altitude of the first contour line Incidence (Up)

The lowest river basin elevation

The highest river basin elevation

A part of the river basin consisted of a very permeable products from rocks(fp)

A part of the river basin area consisted of medium permeable rocks (fpp)

A part of the river basin consisted of poor water permeability rocks (f0)

A part of the river basin under forests ( $f s$ )

A part of the river basin under grass, meadows, pastures, and orchards ( $\mathrm{ft}$ )

A part of the river basin under bare land, plough-land, and ground without grass vegetation (fg)

The total length of the main watercourse with tributaries of I and II class

The shortest distance between the fountainhead and mouth(Lm)

The volume of the torrent rain $(\mathrm{hb})$

Average annual air temperature (t0)

Average annual precipitation (H year)

Amount and Unit
$2055.75 \mathrm{~km}^{2}$
$102.69 \mathrm{~km}$
$1188.01 \mathrm{~km}^{2}$
$867.73 \mathrm{~km}^{2}$
$102.6 \mathrm{~km}$
$8921 \mathrm{~km}$
$300 \mathrm{~m}$
100 years
$213 \mathrm{~m}$
$4003 \mathrm{~m}$
0.114
0.883
0.003
0.337
0.494
0.169
$1574.32 \mathrm{~km}$
$18.78 \mathrm{~km}$
$50.7 \mathrm{~mm}$
$17.0^{\circ} \mathrm{C}$
$729.2 \mathrm{~mm}$



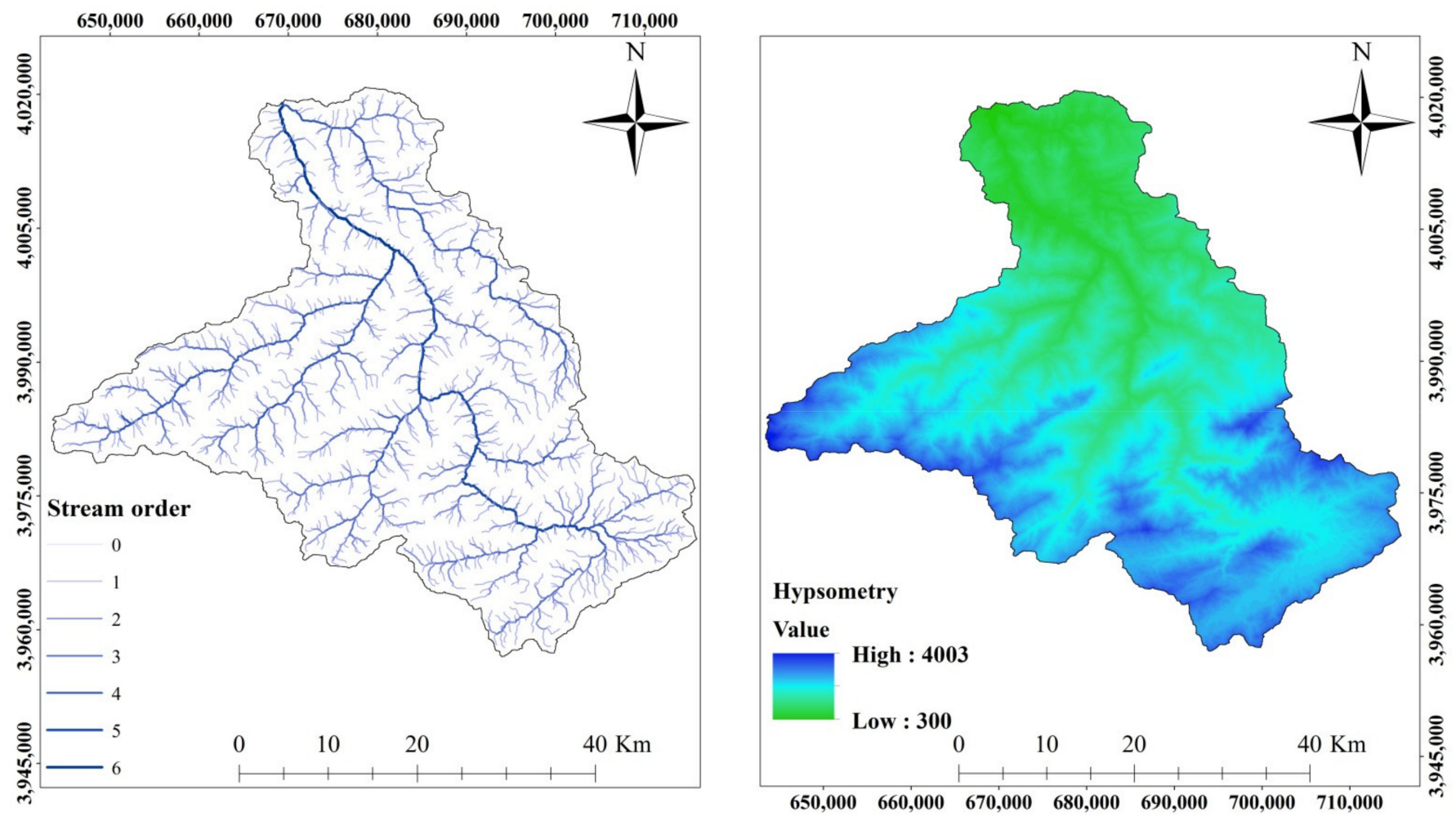

Figure 3. Stream order and hypsometry maps of the Talar watershed.

The annual volume of soil detached due to soil erosion $\left(W_{\text {year }}\right)$ was calculated in $\mathrm{m}^{3} \mathrm{~km}^{-2} \mathrm{y}^{-1}$ by the following Equation (1) $[11,19,29,41]$ :

$$
\text { Wyear }=T \times P \times \pi \times \sqrt{Z^{3}} \times F s
$$

$P$ is the annual average rainfall in $\mathrm{mm}$,

$T$ is the temperature coefficient, calculated from the following equation $[11,29,41]$ :

$$
T=\sqrt{\frac{t}{10}+0.1}
$$

$t$ represents the mean annual temperature in ${ }^{\circ} \mathrm{C}$ which is extracted from the meteorological data collected from the Meteorological Organization of Iran.

The $Z$ coefficient describes the intensity of the erosive process. It is calculated using the following equation $[11,19,29,41]$ :

$$
Z=X \times Y \times(\Phi+\sqrt{I})
$$

$X$ represents the coefficient of soil protection (Table 2), it is a dimensionless parameter based on the vegetal cover and catchment's land use, and it varies from 0.05 to 1; values close to 0 indicate low soil protection while values close to 1 mean high soil protection [42].

$Y$ is soil erodibility coefficient (Table 2), which depends on the pedological and lithological characteristics of the watershed. It indicates the resistance of lithological units and soils to erosion.

The values of this dimensionless factor, which is usually between 0.25 and 2, can be determined either by field measurements or by laboratory experiments $[40,42]$. Lower values indicate low erodibility, whereas higher values represent strongly erodible formations $[42,43]$. In the present study, the pedological and the geological map and data of the study area were used to evaluate the $Y$ factor. Then, the coefficient values were assigned to each soil type based on the EPM guidelines and previous studies [42,44-47]. 
Table 2. Values of the $\mathrm{Y}, \mathrm{X}$ a and $\Phi$ factors used in the Erosion potential method (EPM)/IntErO model.

\begin{tabular}{cc}
\hline Coefficient of Soil Cover & $\boldsymbol{X}$ Value \\
\hline Areas Without Vegetal Cover (Bare Land, Building Area, Water) & $0.8-0.9$ \\
Crop Fields, Meadows, Grasslands & $0.6-0.8$ \\
Built-up Areas and Crops, Degraded Shrublands & $0.4-0.6$ \\
Arboricultural Lands, Clear Shrublands & $0.2-0.4$ \\
Reforested Areas, Dense Forests, Dense Shrublands & $0.05-0.2$ \\
\hline Coefficient of Soil Resistance & $\boldsymbol{Y}$ Value \\
\hline Marls, Clays, Poorly Consolidated Sands, Rock With Little Resistance & $1.3-1.7$ \\
Weak Rock, Clayey Pelites With Microbereccia Beds, Recent Quaternary Scree & $1-1.3$ \\
Rock With Moderate Erosion Resistance, Quaternary Fluvial Terraces & $0.6-1$ \\
Hard Rock, Sandstone of the Numidian Nappe & $0.5-0.6$ \\
\hline Coefficient of Type and Extent of Erosion & $\mathbf{\Phi}$ Value \\
\hline Deep Ravines, Landslides, Badlands Areas, and Bank Undercutting & $0.8-0.9$ \\
Sheet Erosion, Less than 50\% of the Basin Area With Rill and Gullies Erosion & $0.6-0.7$ \\
$20 \%$ of the Area Attacked by Surface Erosion, Minor Slips in Stream Channels & $0.3-0.5$ \\
Land Surface Without Visible Erosion, Mostly Crop Fields & $0.1-0.2$ \\
\hline
\end{tabular}

$\Phi$ coefficient depends on the active erosion and on the degree of extension of linear erosion and mass movements (Table 2). It is also a dimensionless factor ranged from 0.1 to $1[48,49]$. Each type of erosion form was accordingly related to a value of $\Phi$ based on the guidelines of the EPM method [42,44,47]. Finally, the weighted average value was calculated based on the area of all polygons with various values [31].

The total volume of sediment produced in the different areas of the watershed does not fully reach the main river stem. A portion of it is redeposited at the slope foot or deposited in upstream tributaries alluvial plain; therefore, it is essential to calculate the actual specific sediment production (Gsp) in $\mathrm{m}^{3} \mathrm{~km}^{-2} \mathrm{y}^{-1}$ by the following equation [11,19]:

$$
\text { Gsp }=\text { Wyear } \times R u
$$

This is possible by multiplying the average annual production of sediments Wyear by a delivery ratio coefficient $R u$ calculated as

$$
R u=\frac{\sqrt{O \times D}}{0.25 \times(L v+10)}
$$

$L v$ represents the length of the main river in $\mathrm{km}, \mathrm{O}$ is the perimeter of the catchment area in $\mathrm{km}$, and $D$ is the average elevation (in $\mathrm{m}$ ) of the basin with respect to the closing section.

The Maximum flow discharge, Qmax, was calculated using the following formula:

$$
Q \max =\mathrm{A} \times \mathrm{S} 1 \times \mathrm{S} 2 \times \mathrm{W} \times \sqrt{(2 \times \mathrm{g} \times \mathrm{D} \times \mathrm{F})}
$$

$A$ represents the basin shape coefficient and is computed by the following formula:

$$
\mathrm{A}=0.195 \times \frac{\mathrm{O}}{\mathrm{Lv}}
$$

$\mathrm{S} 1$ is the coefficient of water permeability of the area calculated from the following equation:

$$
\mathrm{S} 1=0.4 \times \mathrm{fp}+0.7 \times \mathrm{fpp}+1.0 \times \mathrm{fo}
$$

Coefficients $\mathrm{fp}$, fpp, and fo are the parts of the river basin that consist rocks of high, medium, and low permeability, respectively. 
$\mathrm{S} 2$ is vegetation cover coefficient computed from the following equation:

$$
\mathrm{S} 2=0.6 \times \mathrm{fs}+0.8 \times \mathrm{ft}+1.0 \times \mathrm{fg}
$$

Coefficients $\mathrm{fs}$, $\mathrm{ft}$, and $\mathrm{fg}$ are the parts of the river basin under forest (fs), grass, meadows, pastureland, and orchards (ft), and bare land, plough land, and soils without grass vegetation $(\mathrm{fg})$.

$\mathrm{W}$ is analytical expression of inflowing water retention and is presented by the following equation:

$$
\mathrm{W}=\mathrm{hb} \times(15-22 \times \mathrm{hb}-0.3 \times \sqrt{\mathrm{Lv}})
$$

$\mathrm{hb}$ is torrential rain volume in meters, $\mathrm{g}$ is acceleration due to gravity $\left(\mathrm{m} \mathrm{s}^{-2}\right), \mathrm{D}$ is mean height difference of the basin in meters.

$\mathrm{F}$ is basin area in $\mathrm{km}^{2}$.

\section{Results}

\subsection{Land Use Changes (1991-2014)}

Landsat satellite images for 1991 and 2014 and the maximum likelihood method were used to prepare the land use map for the Talar watershed (Figure 4). The study area was classified into five classes including forest, rainfed agriculture, irrigated agriculture, residential area, and rangeland. The comparison of land use change between these two periods indicates that the forest decreased by $12,478.04$ ha $(6 \%)$, whereas rainfed agriculture and rangeland increased by 3.49 and $2.18 \%$, respectively (Table 3 ). Irrigated agriculture and residential remained almost the same (Table 3).

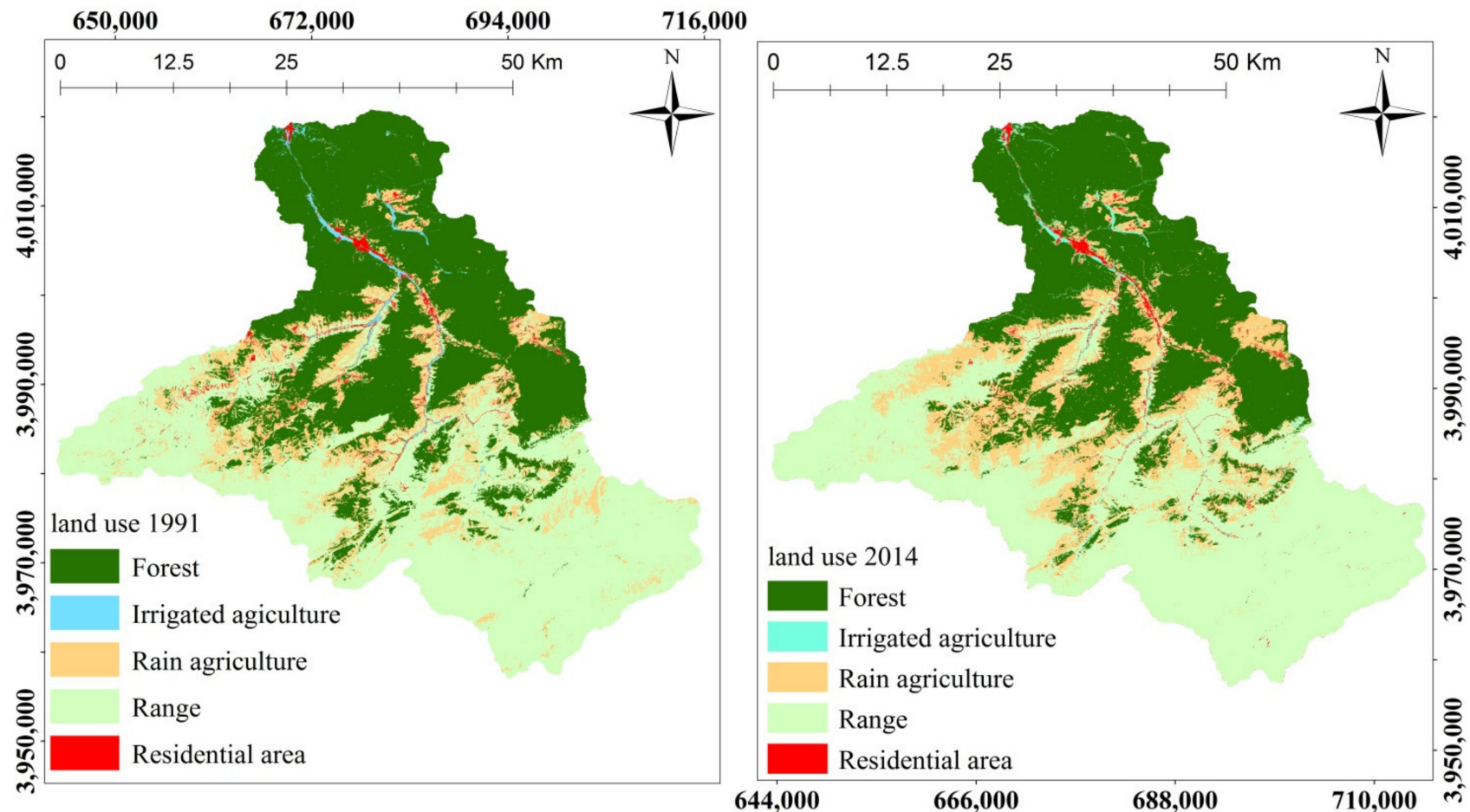

Figure 4. Land use maps of Talar watershed for the year 1991 (left) and 2014 (right). 
Table 3. The results of land use change between 1991 and 2014 in Talar watershed.

\begin{tabular}{|c|c|c|c|c|c|c|}
\hline \multirow{2}{*}{ Land Use Type } & \multicolumn{2}{|c|}{ Land Use 1991} & \multicolumn{2}{|c|}{ Land Use 2014} & \multicolumn{2}{|c|}{ Changes (1991-2014) } \\
\hline & Area (ha) & Percent & Area (ha) & Percent & Area (ha) & Percent \\
\hline Forest & $83,902.75$ & 40.82 & $71,424.71$ & 34.79 & $-12,478.04$ & -6.03 \\
\hline Irrigated agriculture & 1017.82 & 0.49 & 1493.82 & 0.72 & +476.00 & +0.23 \\
\hline Rainfed agriculture & $23,272.06$ & 11.32 & $30,520.31$ & 14.81 & +7248.25 & +3.49 \\
\hline Rangeland & $95,826.45$ & 46.61 & $100,307.50$ & 48.79 & +4481.05 & +2.18 \\
\hline Residential area & 1563.77 & 0.76 & 1837.72 & 0.89 & +273.95 & +0.13 \\
\hline
\end{tabular}

\subsection{Climatic Characteristics, Geological Structure, and Soil Characteristics of the Studied Area}

The average annual temperature and precipitation were calculated $17^{\circ} \mathrm{C}$ and $729 \mathrm{~mm}$ based on the Gharakheil meteorological station data. The geology information was obtained from the geological map of Iran [50]. The description of type and area (Ha) of the different formations are reported in Table 4. The Dark grey shale and sandstone, called Shemshak formation, underlie the largest area with 936.3 ha. There are three types of permeability class of formation considered in the IntErO model such as poor water permeability rocks (f0) (Class 1), medium permeable rocks (fpp) (Class 2) and very permeable products from rocks (fp) (Class 3 ) which occur in $0.3 \%, 88.2 \%$, and $11.4 \%$, respectively, of the watershed area. The geology and soil maps are shown in Figure 5.

Table 4. The geolithological unites for study area of the Talar watershed and permeability classes.

\begin{tabular}{|c|c|c|c|}
\hline Num & Description & Class & Area (ha) \\
\hline 1 & Alternation of dolomite, limestone, and variegated shale & 2 & 50.7 \\
\hline 2 & Basaltic volcanic tuff & 3 & 6.9 \\
\hline 3 & Conglomerate and sandstone & 2 & 3.0 \\
\hline 4 & Conglomerate, sandstone, and shale with plantremains and coal seams & 2 & 19.4 \\
\hline 5 & Dark grey medium—bedded to massive limestone & 2 & 14.7 \\
\hline 6 & Dark grey shale and sandstone & 2 & 936.3 \\
\hline 7 & High level piedmont fan and valley terrace deposits & 1 & 16.0 \\
\hline 8 & Hyporite bearing limestone & 1 & 16.1 \\
\hline 9 & Light-red coarse grained, polygenic conglomerate with sandstone intercalations & 2 & 6.1 \\
\hline 10 & Light grey, thin-bedded to massive limestone & 2 & 135.3 \\
\hline 11 & Light-red to brown marl and gypsiferous marl with sandstone intercalations & 2 & 0.5 \\
\hline 12 & Low level piedmont fan and valley terrace deposits & 1 & 8.0 \\
\hline 13 & Marl, calcareous sandstone, sandy limestone, and minor conglomerate & 2 & 156.0 \\
\hline 14 & Marl, gypsiferous marl and limestone & 2 & 197.1 \\
\hline 15 & Nummulitic limestone & 2 & 10.7 \\
\hline 16 & Polymictic conglomerate and sandstone & 2 & 120.7 \\
\hline 17 & Red conglomerate and sandstone & 2 & 1.4 \\
\hline 18 & Red marl, gypsiferous marl, sandstone, and conglomerate & 2 & 6.1 \\
\hline 19 & Swamp and marsh & 1 & 1.1 \\
\hline 20 & Thick—bedded to massive limestone & 2 & 13.2 \\
\hline 21 & $\begin{array}{l}\text { thick bedded grey o'olitic limestone; thin-platy, yellow to pinkish shaly limestone } \\
\text { with worm tracks and well to thick—-bedded dolomite and dolomitic limestone }\end{array}$ & 2 & 62.3 \\
\hline 22 & Thick bedded to massive, white to pinkish orbitolina bearing limestone & 2 & 41.9 \\
\hline 23 & Undifferentiated limestone, shale, and marl & 2 & 13.9 \\
\hline 24 & Undifferentiated lower Paleozoic rocks & 1 & 27.0 \\
\hline 25 & Undifferentiated unit, composed of dark red micaceous siltstone and sandstone & 2 & 16.6 \\
\hline 26 & Upper cretaceous, undifferentiated rocks & 1 & 78.7 \\
\hline 27 & $\begin{array}{c}\text { Well-bedded to thin—bedded, greenish-grey argillaceous limestone with } \\
\text { intercalations of calcareous shale }\end{array}$ & 2 & 8.4 \\
\hline 28 & Well bedded green tuff and tuffaceous shale & 1 & 87.7 \\
\hline
\end{tabular}



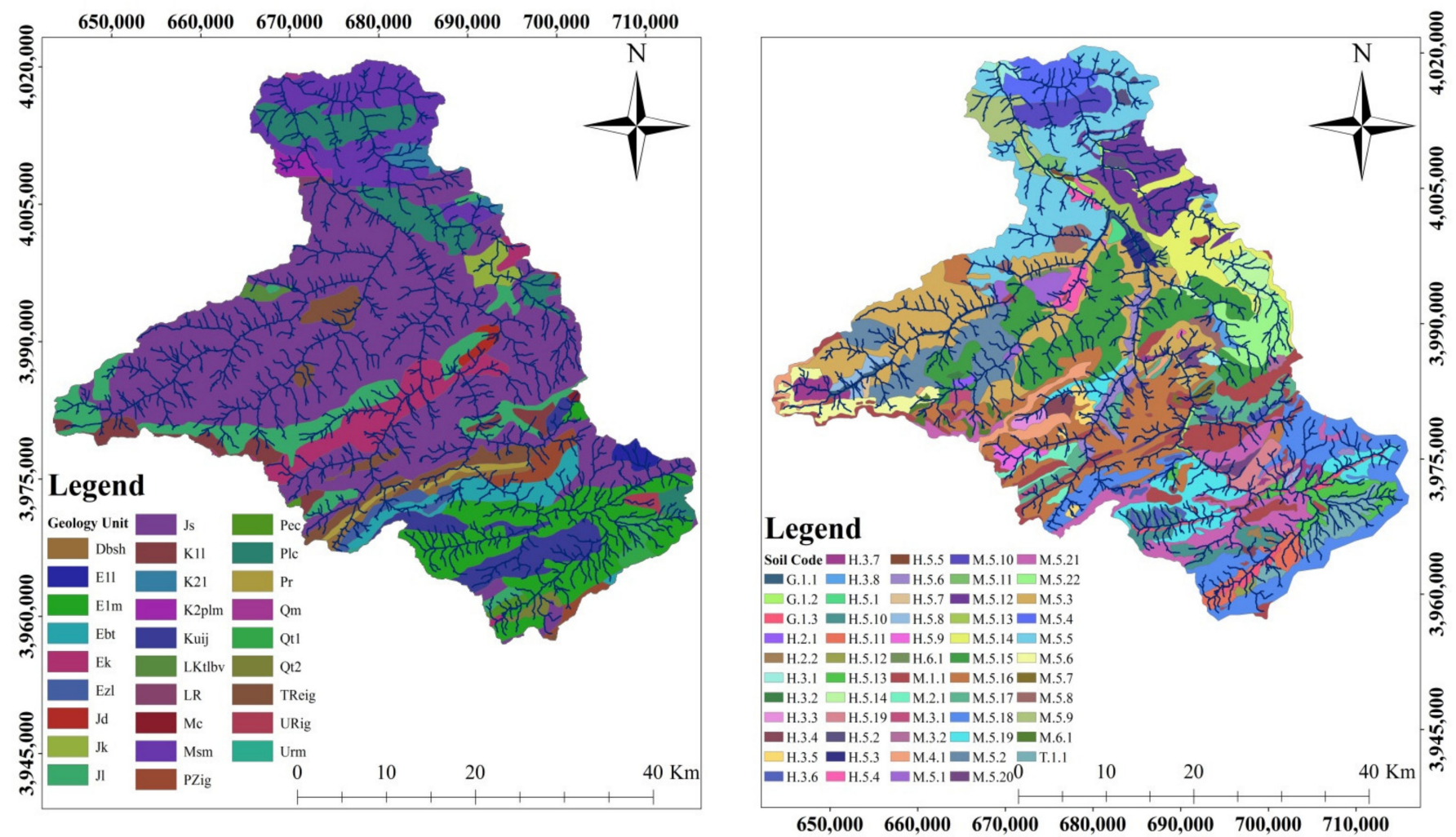

Figure 5. Geology (left) and soil (right) maps of Talar watershed.

\subsection{Vegetation and Land Use}

The land use map shows that in 2014 forest, irrigated land, rainfed agriculture, rangeland and residential areas cover $34.8 \%, 0.7 \%, 14.8 \%, 48.8 \%$, and $0.9 \%$, respectively, of the Talar watershed area. Most of the basin is covered by rangeland and forestland. The coefficient of the river basin planning $(\mathrm{Xa})$ and the coefficient of the vegetation cover $\left(\mathrm{S}_{2}\right)$ and Numeral equivalents of visible and clearly exposed erosion process $(\Phi)$ are calculated and shown in Table 5.

\subsection{Soil Erosion and Runoff Characteristics}

The data presented in Table 6 describe the result of calculation of the IntErO model for the Talar watershed. The coefficients of the river basin form (A), average river basin width (B) and watershed development $(\mathrm{m})$ were calculated to be $0.2,29.88 \mathrm{~km}$, and 0.63 , respectively. The value of peak discharge, with a return interval of 100 years $\left(\mathrm{Q}_{100}\right)$ and for a land use setup of 2014 resulted $446.91 \mathrm{~m}^{3} \mathrm{~s}^{-1}$. The (A) symmetry of the river basin was calculated as 0.31 , which indicates that there is a possibility for large flood waves to appear in the studied river basin. In other word, the probability of large flood waves is about once per three year. $\mathrm{Q}_{100}$, in fact, is about five times larger than the maximum discharge measured in the 1971-1998 interval for which a maximum return interval of 28 years can be optimistically assumed. In the recent decades human activities such as urban development and land use changes have increased flood hazard and watershed vulnerability to rainfalls and rain storms and an increase of peak flows is to be expected [51,52]. 
Table 5. The Y, Xa, and $\Phi$ coefficients for land use 2014.

\begin{tabular}{|c|c|c|}
\hline Types of Soil Products and Related Types & $\mathbf{Y}$ & Area $(\%)$ \\
\hline Sands, gravel, and loose soils & 2.00 & 1.17 \\
\hline Loess, tuffs, saline, steppe soils & 1.60 & 0.00 \\
\hline Disintegrated limestone and marl & 1.20 & 11.3 \\
\hline Serpentine soil, red sandstones, flysch deposits & 1.10 & 2.66 \\
\hline Podzols and parapodzols, disintegrated shales & 1.00 & 0.00 \\
\hline Compact and shaley limestone, red soils, and humus silicate soils & 0.90 & 45.16 \\
\hline Eutric cambisols and mountain soils & 0.80 & 33.33 \\
\hline Vertisols, boggy ploughand and marsh soils & 0.60 & 0.00 \\
\hline Chernozem and alluvial sediments of good structure & 0.50 & 1.16 \\
\hline Bare, compact eruptives & 0.25 & 2.23 \\
\hline Types of Land Use & Xa & Area $(\%)$ \\
\hline Bare land & 1.00 & 1.72 \\
\hline Plough land & 0.90 & 16.43 \\
\hline Orchards and vineyards & 0.70 & 0.00 \\
\hline Mountain pastures & 0.60 & 48.15 \\
\hline Meadows & 0.40 & 0.00 \\
\hline Degraded forests & 0.60 & 13.70 \\
\hline Forests of good spacing & 0.05 & 20.00 \\
\hline Erosion Conditions & $\Phi$ & Area $(\%)$ \\
\hline Deep erosion & 1.00 & 2.02 \\
\hline $80 \%$ of basin under rill and gully erosion & 0.90 & 3.03 \\
\hline $50 \%$ of basin under rill and gully erosion & 0.80 & 6.06 \\
\hline $100 \%$ of basin under surface erosion & 0.70 & 8.08 \\
\hline $100 \%$ of basin under surface erosion without visible rills, gullies, and landslides & 0.60 & 15.15 \\
\hline $50 \%$ of basin under surface erosion & 0.50 & 8.08 \\
\hline $20 \%$ of basin under surface erosion & 0.30 & 8.08 \\
\hline Minor slides in watercourses beds & 0.20 & 1.01 \\
\hline Basin mostly under ploughland & 0.15 & 14.14 \\
\hline Basin under forests and perennial vegetation & 0.10 & 34.34 \\
\hline
\end{tabular}

Table 6. The outputs of the IntErO for Talar watershed.

\begin{tabular}{|c|c|c|}
\hline Output Variables & Amount and Unit (1991) & Amount and Unit (2014) \\
\hline Coefficient of the river basin form & 0.2 & 0.2 \\
\hline Coefficient of the watershed development & 0.63 & 0.63 \\
\hline Average river basin width & $29.88 \mathrm{~km}$ & $29.88 \mathrm{~km}$ \\
\hline (A) symmetry of the river basin & 0.31 & 0.31 \\
\hline Density of the river network of the basin & 0.77 & 0.77 \\
\hline Coefficient of the river basin tortuousness & 5.4 & 5.4 \\
\hline Average river basin altitude & $1807.87 \mathrm{~m}$ & $1807.87 \mathrm{~m}$ \\
\hline Average elevation difference of the river basin & $1594.87 \mathrm{~m}$ & $1594.87 \mathrm{~m}$ \\
\hline Average river basin decline & 43.4 & $43.4 \%$ \\
\hline The height of the local erosion base of the river basin & $3790 \mathrm{~m}$ & $3790 \mathrm{~m}$ \\
\hline Coefficient of the erosion energy of the river basin's relief & 179.16 & 179.16 \\
\hline Coefficient of the region's permeability & 0.67 & 0.67 \\
\hline Coefficient of the vegetation cover & 0.74 & 0.77 \\
\hline Analytical presentation of the water retention in inflow & $0.5507 \mathrm{~m}$ & $0.5507 \mathrm{~m}$ \\
\hline Energetic potential of water flow during torrent rains & $8020.44 \mathrm{~m} \mathrm{~km} \mathrm{~s}$ & $8020.44 \mathrm{~m} \mathrm{~km} \mathrm{~s}$ \\
\hline Maximum flow discharge $\left(\mathrm{Q}_{100}\right)$ & $432.14 \mathrm{~m}^{3} \mathrm{~s}^{-1}$ & $446.91 \mathrm{~m}^{3} \mathrm{~s}^{-1}$ \\
\hline Temperature coefficient of the region & 1.34 & 1.34 \\
\hline Coefficient of the river basin erosion & 0.452 & 0.492 \\
\hline Production of erosion material in the river basin & $1,918,186 \mathrm{~m}^{3} \mathrm{yr}^{-1}$ & $2,183,558 \mathrm{~m}^{3} \mathrm{yr}^{-1}$ \\
\hline Coefficient of the deposit retention & 0.23 & 0.23 \\
\hline Real soil losses per year & $440,482.4 \mathrm{~m}^{3} \mathrm{yr}^{-1}$ & $501,421.3 \mathrm{~m}^{3} \mathrm{yr}^{-1}$ \\
\hline Real soil losses per year per $\mathrm{km}^{2}$ & $214.27 \mathrm{~m}^{3} \mathrm{~km}^{-2} \mathrm{yr}^{-1}$ & $243.91 \mathrm{~m}^{3} \mathrm{~km}^{-2} \mathrm{yr}^{-1}$ \\
\hline
\end{tabular}


The drainage density of the study river basin $(G)$ we calculated as $0.77 \mathrm{~km} \mathrm{~km}^{-2}$. The $G$ index indicates that there is a medium density of the hydrographic network in the Talar watershed. The drainage density is an important factor affecting the flood hydrograph and erosion process. This index depends on the amount of flow through the channel and on soil type [52-54]. The index of average river basin decline we calculated to be $43.4 \%$. The value of this index shown that in the studied watershed very steep slopes prevail.

The Height of the river basin local erosion base and the coefficient of basin erosion energy were calculated to be $3790 \mathrm{~m}$ and $179.16 \mathrm{~m}$, respectively.

According to the IntErO report $\mathrm{Z}$ coefficient is calculated to be 0.492 . That indicates that the study area belongs to the 3rd destruction category (out of five); with the medium strength of the erosion process, where the surface erosion is predominant.

The production of erosion material in the Talar watershed was calculated to be 2,183,558.33 $\mathrm{m}^{3}$ year $^{-1}$ and the coefficient of the deposit retention (sediment delivery ration) resulted 0.23 . It means that $23 \%$ of the total eroded material reaches the outlet point whereas the remaining $77 \%$ is deposited on the basin slopes and within the hydrological drainage system. The detailed report for Talar watershed hydro morphological parameters is shown in Table 6.

Most of the outputs presented are based on the multiplication of the model parameters, except the Coefficient of the Drainage density $(\mathrm{D})$, Average annual temperature $\left(\mathrm{T}_{0}\right)$, and the Average slope of the basin (I). According to Dragičević et al. [51], most of these parameters are categorized as high- or medium-sensitivity, whereas those in the multiplication form are classified as very high-sensitivity parameters.

Calculated Real soil losses per year per square kilometer for the studied river basin amounts to $243.91 \mathrm{~m}^{3} \mathrm{~km}^{-2} \mathrm{yr}^{-1}$ (2014). This result corresponds to the results obtained in 2014 for the similar and nearby ShirinDareh watershed from the North Iran: S1-1 ShirinDareh sub-basin $224.30 \mathrm{~m}^{3} \mathrm{~km}^{-2} \mathrm{yr}^{-1}$ [36]; S1-2, $363.98 \mathrm{~m}^{3} \mathrm{~km}^{-2} \mathrm{yr}^{-1}$ [52]; S1-4, $237.25 \mathrm{~m}^{3} \mathrm{~km}^{-2} \mathrm{yr}^{-1}$ [53]; S1-5, 230.86 $\mathrm{m}^{3} \mathrm{~km}^{-2} \mathrm{yr}^{-1}$ [37]; S1-6, $200.88 \mathrm{~m}^{3} \mathrm{~km}^{-2} \mathrm{yr}^{-1}$ [54]; what is in average $251.45 \mathrm{~m}^{3} \mathrm{~km}^{-2} \mathrm{yr}^{-1}$.

The soil erosion and the actual soil losses based on the land use in 1991 and in 2014 are presented at the Figure 6.

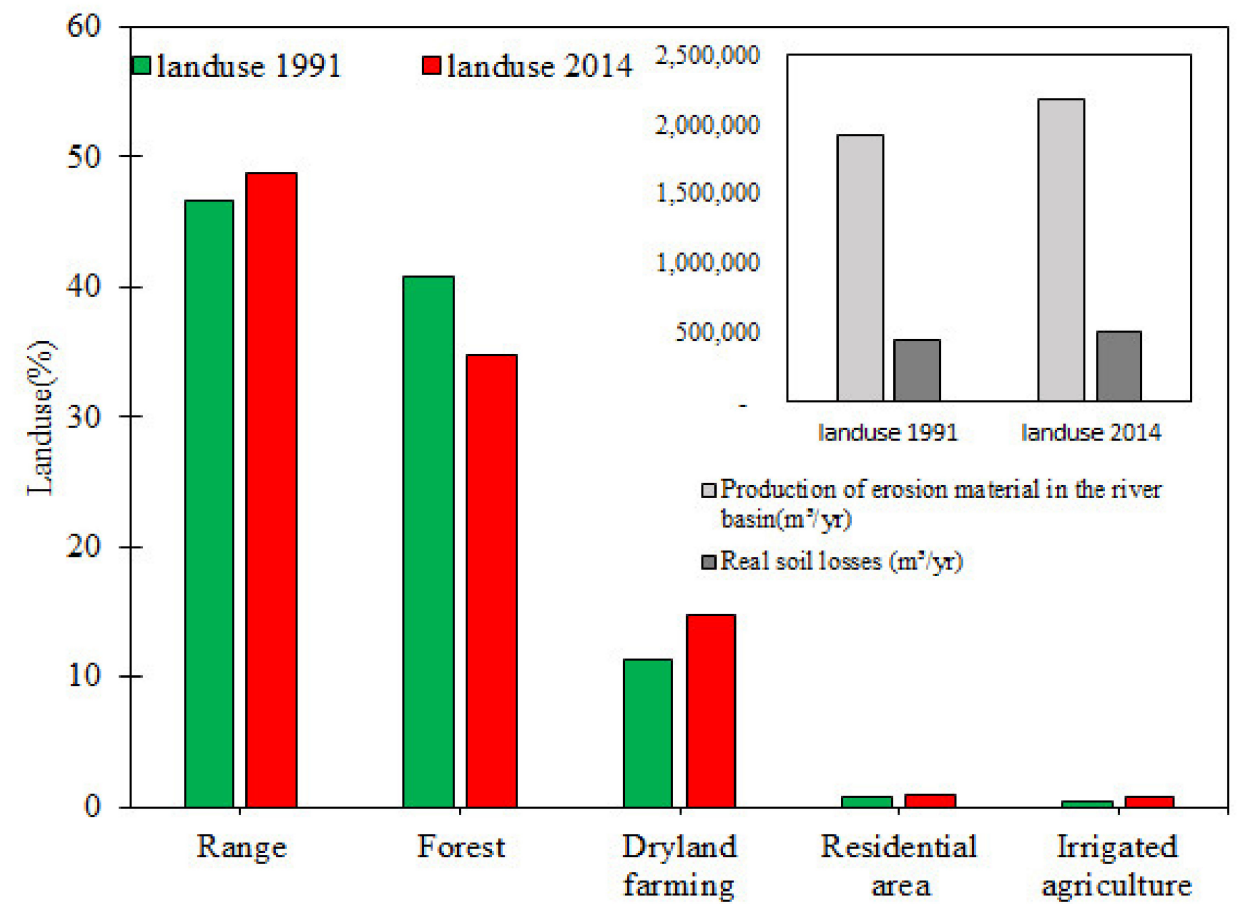

Figure 6. Land use changes (1991-2014), production of erosion material and real soil losses. 
Taking into consideration the land use changes in the study catchment reported in the Table 3, the most relevant changes in the Talar are a decrease by $6 \%$ of forest lands and an increase of about $4 \%$ in agricultural land. The maximum outflow $\left(Q_{100}\right)$ increase by $14 \mathrm{~m}^{3} \mathrm{~s}^{-1}(3.41 \%)$ with land use of 2014 . In addition, the amount of sediment production (eroded material) in the river basin and real soil loss increases by $265,372 \mathrm{~m}^{3} \mathrm{yr}^{-1}(6 \%)$ and $60,938.9 \mathrm{~m}^{3} \mathrm{yr}^{-1}(12 \%)$, respectively. These findings are in line with other studies findings that the degradation and reduction of forest lands and the development of agricultural lands is commonly associated with an increase of flow and sediment yield [55-64].

The best measure for protection of soil erosion processes and torrential floods is prevention. Establishment of this structured IntErO database for the studied Talar river basin will support in the future planning of permanent control of erosion processes, which will be achieved by an integral river basin management system [65].

Findings from this research are in line with Rodrigo-Comino et al. [66] who clearly demonstrate that the soil erosion intensity is highly dependent on the agriculture use. Furthermore, various strategies and research reports have shown the importance of grown cultures rotation to control the soil losses [30]. The key management aspect to control the soil losses is agriculture and this is clear in many crops: vineyards [66], olive [67], and the other cultures, what leads to the decrease in soil erosion intensity because of the vegetation recovery [68].

\section{Conclusions}

Mazandaran Province is one of the northern provinces of Iran, which experienced an appreciable land use change throughout the last three decades. Over more than two decades, in the Talar watershed, a large part of the forest area decrease of about $30 \%$ due to road and urban development, mine exploration, and construction of factories. In addition, a large amount of rangelands was turned into agricultural as part of rural areas development programs. All these changes have accelerated soil erosion process. In this study, the IntErO model was used to predict the effect of land use change on soil erosion and sediment yield in the Talar watershed. According to the model results, we concluded that an increase in flood intensity has to be expected following the recent land use change. The study showed that the Talar basin belongs to the third destruction category (out of five), i.e., erosion process is medium and erosion type is predominantly surface erosion. The degradation of forest lands, the development of agricultural land and the conversion of rangelands into rainfed farming is leading to an increase of peak flow and sediment yield in the Talar watershed. The IntErO model proved to be a suitable tool for assessing the watershed response to land use change in terms of peak flow, erosion, and sediment yield, especially in countries with data limitation. The projected climate changes in rainfall amounts and intensity, predicted for the Middle East, may exacerbate the effects of the land use change and remarkably increasing the current hazard level.

Author Contributions: Conceptualization, M.M., A.K.D., and V.S.; methodology, M.M., A.K.D., and V.S.; software, V.S.; formal analysis, M.M., A.K.D., V.S., B.D., and P.B; investigation, M.M., A.K.D., V.S., B.D., and P.B; data curation, M.M., A.K.D., and V.S.; writing-original draft preparation, M.M., A.K.D., and V.S.; writing-review and editing, M.M., A.K.D., V.S., B.D., and P.B.; supervision, A.K.D. and V.S. All authors have read and agreed to the published version of the manuscript.

Funding: This research received no external funding.

Acknowledgments: The Authors are grateful for support of the organizers of the Green room Sessions 2018 International GEA (Geo Eco-Eco Agro) Conference (www.greenrooms.ucg.ac.me, accessed on 22 March 2021) for funding participation of some of the authors to provide the main findings of this research as Oral presentation, with publishing the Abstract of this research in the Conference Book of Abstracts [69].

Conflicts of Interest: The authors declare no conflict of interest. 


\section{References}

1. Eswaran, H.; Lal, R.; Reich, P.F. Land degradation: An overview. In Responses to Land Degradation; Oxford Press: New Delhi, India, 2001; pp. 20-35.

2. Zabihi, M.; Mirchooli, F.; Motevalli, A.; Khaledi Darvishan, A.; Pourghasemi, H.R.; Zakeri, M.A.; Sadighi, F. Spatial modelling of gully erosion in Mazandaran Province, northern Iran. Catena 2018, 161, 1-13. [CrossRef]

3. Khaledi Darvishan, A.; Homayounfar, V.; Sadeghi, S.H. The impact of standard preparation practice on the runoff and soil erosion rates under laboratory conditions. Solid Earth 2016, 7, 1293-1302. [CrossRef]

4. Khaledi Darvishan, A.; Sadeghi, S.H.; Homaee, M.; Arabkhedri, M. Measuring sheet erosion using synthetic color-contrast aggregates. Hydrol. Processes 2014, 28, 4463-4471. [CrossRef]

5. Turner, B.L.; Clark, W.C.; Kates, R.W.; Richards, J.F.; Mathews, J.T.; Meyer, W.B. The Earth as Transformed by Human Action; Cambridge University Press: Cambridge, UK, 1990.

6. Dabral, P.P.; Baithuri, N.; Pandey, A. Soil erosion assessment in a hilly catchment of North Eastern India using USLE, GIS and remote sensing. Water Resour. Manag. 2008, 22, 1783-1798. [CrossRef]

7. Kavian, A.; Gholami, L.; Mohammadi, M.; Spalevic, V.; Soraki, M.F. Impact of Wheat Residue on Soil Erosion Processes. Not. Bot. Horti Agrobot. Cluj-Napoca 2018, 46, 553-562. [CrossRef]

8. Ferreira, V.; Panagopoulos, T.; Cakula, A.; Andrade, R.; Arvela, A. Predicting soil erosion after land use changes for irrigating agriculture in a large reservoir of southern Portugal. Agric. Agric. Sci. Procedia 2015, 4, 40-49. [CrossRef]

9. Li, T.; Liu, K.; Ma, L.; Bao, Y.; Wu, L. Evaluation on Soil Erosion Effects Driven by Land Use Changes over Danjiang River Basin of Qinling Mountain. J. Nat. Resour. 2016, 4, 4 .

10. Wang, W.; Shao, Q.; Yang, T.; Peng, S.; Xing, W.; Sun, F.; Luo, Y. Quantitative assessment of the impact of climate variability and human activities on runoff changes: A case study in four catchments of the Haihe River basin, China. Hydrol. Processes 2013, 27, 1158-1174. [CrossRef]

11. Spalevic, V.; Barovic, G.; Vujacic, D.; Curovic, M.; Behzadfar, M.; Djurovic, N.; Dudic, B.; Billi, P. The Impact of Land Use Changes on Soil Erosion in the River Basin of Miocki Potok, Montenegro. Water 2020, 12, 2973. [CrossRef]

12. Parteli, E.J.; Da Silva, L.R.; Andrade, J.S., Jr. Self-organized percolation in multi-layered structures. J. Stat. Mech. Theory Exp. 2010, 2010, P03026. [CrossRef]

13. Ghanbarian, B.; Sahimi, M.; Daigle, H. Modeling relative permeability of water in soil: Application of effective-medium approximation and percolation theory. Water Resour. Res. 2016, 52, 5025-5040. [CrossRef]

14. Efthimiou, N.; Lykoudi, E.; Panagoulia, D.; Karavitis, C. Assessment of soil susceptibility to erosion using the EPM and RUSLE Models: The case of Venetikos River Catchment. Glob. NEST J. 2016, 18, 164-179.

15. Panagoulia, D.; Zarris, D.; Maggina, K. An assessment of the interaction between storm events and sediment transport. In Proceedings of the 5th International Synposium on Ecohydraulics, Aguatic Habitats: Analysis \& Restoration, Madrid, Spain, 12-17 September 2004; pp. 12-17.

16. Lazzari, M.; Gioia, D.; Piccarreta, M.; Danese, M.; Lanorte, A. Sediment yield and erosion rate estimation in the mountain catchments of the Camastra artificial reservoir (Southern Italy): A comparison between different empirical methods. Catena 2015, 127, 323-339. [CrossRef]

17. Prasannakumar, V.; Shiny, R.; Geetha, N.; Vijith, H. Spatial prediction of soil erosion risk by remote sensing, GIS and RUSLE approach: A case study of Siruvani river watershed in Attapady valley, Kerala, India. Environ. Earth Sci. 2011, 64, 965-972. [CrossRef]

18. Gavrilovic, S. A method for estimating of the average annual quantity of sediments according to the potency of erosion. Bull. Fac. For. 1962, 26, 151-168.

19. Gavrilovic, S. Engineering of Torrential Flows and Erosion; Izgradnja: Belgrade, Serbia, 1972; 272p.

20. Blinkov, I.; Kostadinov, S. Applicability of various erosion risk assessment methods for engineering purposes. In Proceedings of the BALWOIS 2010 Conference-Ohrid, Republic of Macedonia, Ohrid, North Macedonia, 25-29 May 2010; pp. 25-29.

21. Gholami, L.; Batista, P.; Behzadfar, A.; Khaledi Darvishan, A.; Behzadfar, M. Application of IntErO model for soil loss estimation case study: S7-1 Watershed of Shirindareh river basin, Iran. In Proceedings of the 7th International Agricultural Symposium "Agrosym 2016", Jahorina, Bosnia and Herzegovina, 6-9 October 2016; pp. 2169-2177.

22. Lenaerts, T. Geomorphological Mapping of Montenegro: Landform Genesis and Present Processes. Master's Thesis, University of Gent, Faculty of Geography, Gent, Belgium, 2014; p. 128.

23. Spalevic, V.; Curovic, M.; Borota, D.; Fustic, B. Soil erosion in the river basin Zeljeznica, area of Bar, Montenegro. Agric. For. 2012, 54, 5-24.

24. Spalevic, V.; Curovic, M.; Simunic, I.; Behzadfar, M.; Tanaskovic, V. Land degradation, land use and soil erosion: The case of Montenegro. CIHEAM Watch Lett. Land Issues Mediterr. Ctries. 2014, 28, 58-62.

25. Tavares, A.S.; Spalevic, V.; Avanzi, J.C.; Nogueira, D.A.; Silva, M.L.N.; Mincato, R.L. Modelling of water erosion by the erosion potential method in a pilot subbasin in southern Minas Gerais. Semin. Cienc. Agrar. Londrina 2019, 40, 555-572. [CrossRef]

26. Spalevic, V.; Nyssen, J.; Curovic, M.; Lenaerts, T.; Kerckhof, A.; Annys, K.; den Branden, J.; Frankl, A. The impact of land use on soil erosion in the River Basin Boljanska Rijeka in Montenegro. In Proceedings of the 4th International Agricultural Symposium "Agrosym 2013", Jahorina, Bosnia and Herzegovina, 3-6 October 2013; pp. 54-63. 
27. Spalevic, V.; Hübl, J.; Hasenauer, H.; Curovic, M. Calculation of soil erosion intensity in the Bosnjak Watershed, Polimlje River Basin, Montenegro. In Proceedings of the 5th International Agricultural Symposium "Agrosym 2014", Jahorina, Bosnia and Herzegovina, 23-26 October 2014; pp. 730-738.

28. Globevnik, L.; Holjevic, D.; Petkovsek, G.; Rubinic, J. Applicability of the Gavrilovic method in erosion calculation using spatial data manipulation techniques. Int. Assoc. Hydrol. Sci. Publ. 2003, 279, 224-233.

29. Spalevic, V. Impact of Land Use on Runoff and Soil Erosion in Polimlje. Ph.D. Thesis, Faculty of Agriculture, University of Belgrade, Belgrade, Serbia, 2011; pp. 1-260.

30. Chalise, D.; Kumar, L.; Spalevic, V.; Skataric, G. Estimation of Sediment Yield and Maximum Outflow Using the IntErO Model in the Sarada River Basin of Nepal. Water 2019, 11, 952. [CrossRef]

31. Ouallali, A.; Aassoumi, H.; Moukhchane, M.; Moumou, A.; Houssni, M.; Spalevic, V.; Keesstra, S. Sediment mobilization study on Cretaceous, Tertiary and Quaternary lithological formations of an external Rif catchment, Morocco. Hydrol. Sci. J. 2020, 65, 1568-1582. [CrossRef]

32. Mohammadi, M.; Khaledi Darvishan, A.; Bahramifar, N. Spatial distribution and source identification of heavy metals (As, Cr, $\mathrm{Cu}$ and $\mathrm{Ni}$ ) at sub-watershed scale using geographically weighted regression. Int. Soil Water Conserv. Res. 2019, 7, 308-315. [CrossRef]

33. Khaledi Darvishan, A.; Derikvandi, M.; Aliramaee, R.; Khorsand, M.; Spalevic, V.; Gholami, L.; Vujacic, D. Efficiency of IntErO Model to Predict Soil Erosion Intensity and Sediment Yield in Khamsan Representative Watershed (West of Iran). Agrofor Int. J. 2018, 3, 22-31. [CrossRef]

34. Khaledi Darvishan, A.; Mohammadi, M.; Skataric, G.; Popovic, S.; Behzadfar, M.; Rodolfo Ribeiro Sakuno, N.; Luiz Mincato, R.; Spalevic, V. Assessment of soil erosion, sediment yield and maximum outflow, using IntErO model (Case study: S8-IntA Shirindarreh Watershed, Iran). Agric. For. 2019, 65, 203-210. [CrossRef]

35. Behzadfar, A.; Guicardi, C.F.A.; Markoski, M.; Sakuno, R.B.N.; Mincato, L.R.; Moteva, M.; Tanaskovik, V. Calculation of Soil loss from the S7-3 Catchment of the Shirindareh Watershed, Iran using the River Basin Model. Agric. For. 2016, 62, 65-71. [CrossRef]

36. Behzadfar, M.; Tazioli, A.; Vukelic-Shutoska, M.; Simunic, I.; Spalevic, V. Calculation of sediment yield in the S1-1 Watershed, Shirindareh Watershed, Iran. Agric. For. 2014, 60, 207-216.

37. Barovic, G.; Silva, M.L.N.; Batista, P.V.G.; Vujacic, D.; Souza, S.W.; Avanzi Junior, C.; Behzadfar, M.; Spalevic, V. Estimation of sediment yield using the IntErO model in the S1-5 Watershed of the Shirindareh River Basin, Iran. Agric. For. 2015, 61, 233-243. [CrossRef]

38. Yousefi, S.; Kivarz, N.; Ramezani, B.; Rasoolzadeh, N.; Naderi, N.; Mirzaee, S. An Estimation of Sediment by Using Erosion Potential Method and Geographic Information Systems in Chamgardalan Watershed: A Case Study of Ilam Province, Iran. Geodyn. Res. Int. Bull. 2014, 2, 34-41.

39. Spalevic, V. Application of Computer-Graphic Methods in the Studies of Draining Out and Intensities of Ground Erosion in the Berane Valley. Master's Thesis, Faculty of Agriculture of the University of Belgrade, Belgrade, Serbia, $1999 ;$ p. 135.

40. Spalevic, V.; Dlabac, A.; Spalevic, B.; Fustic, B.; Popovic, V. Application of computer-Graphic methods in the research of runoff and intensity of ground erosion-I program "River basins". Agric. For. 2000, 46, 19-36.

41. De Vente, J.; Poesen, J. Predicting soil erosion and sediment yield at the basin scale: Scale issues and semi-quantitative models. Earth-Sci. Rev. 2005, 71, 95-125. [CrossRef]

42. Efthimiou, N.; Lykoudi, E. Soil erosion estimation using the EPM model. In Proceedings of the 14th International Conference of the Geological Society of Greece, Thessaloniki, Greece, 25-27 May 2016; Volume L.

43. Shahabi, H.; Salari, M.; Bin Ahmad, B.; Mohammadi, A. Soil Erosion Hazard Mapping in Central Zab Basin Using EPM Model in GIS Environment. Int. J. Geogr. Geol. 2016, 5, 224-235. [CrossRef]

44. Noori, H.; Siadatmousavi, S.M.; Mojaradi, B. Assessment of sediment yield using RS and GIS at two sub-basins of Dez Watershed, Iran. Int. Soil Water Conserv. Res. 2016, 4, 199-206. [CrossRef]

45. Kojchevska, T. EPM for Soil Loss Estimation in Different Geomorphologic Conditions and Data Conversion by Using GIS. Ph.D. Thesis, Mediterranean Agronomic Institute, Chania, Greece, 2014.

46. Dragičević, N.; Karleuša, B.; Ožanić, N. A review of the Gavrilović method (erosion potential method) application. Građevinar 2016, 68, 715-725.

47. Milanesi, L.; Pilotti, M.; Clerici, A.; Gavrilovic, Z. Application of an improved version of the Erosion Potential Method in Alpine areas. Ital. J. Eng. Geol. Environ. 2015, 1, 17-30.

48. Gavrilovic, Z. Use of an empirical method (Erosion Potential Method) for calculating sediment production and transportation in unstudied or torrential streams. In International Conference on River Regime; Hydraulics Research Ltd.: Wallingford, UK, 1988; pp. 411-422.

49. Staut, M. Recent Erosional Processes in the Catchment of the Dragonja River. Ph.D. Thesis, University of Ljubljana, Ljubljana, Slovenia, 2004.

50. Afshar Harb, A.; Bolourchi, M.; Mehr Parto, M. Geological Quadrangle Map of Iran no. J5 (Bojnurd Sheet), Scale 1: 250,000; Geological Survey of Iran: Tehran, Iran, 1987.

51. Dragičević, N.; Karleuša, B.; Ožanić, N. Erosion Potential Method (Gavrilović Method) Sensitivity Analysis. Soil Water Res. 2017, 12, 51-59. [CrossRef] 
52. Draganic, J.; Silva, M.L.N.; Avanzi, C.J.; Kisic, I.; Spalevic, V. Soil Loss Estimation using the IntErO Model in the S1-2 Watershed of the ShirinDareh River Basin, Iran. In Proceedings of the 9th Congress of the Soil Science Society of Bosnia and Herzegovina, Mostar, Bosnia and Herzegovina, 23-25 November 2015.

53. Spalevic, V.; Barovic, G.; Batista, P.V.G.; Darvishan Khaledi, A.; Behzadfar, M.; Tanaskovik, V. Calculation of sediment yield at the S1-4 catchment of the Shirindareh Watershed of Iran using the Erosion Potential Model. In Proceedings of the 3rd WASWAC Conference, Belgrade, Serbia, 22-26 August 2016.

54. Behzadfar, M.; Djurovic, N.; Simunic, I.; Filipovic, M.; Spalevic, V. Calculation of soil erosion intensity in the S1-6 Watershed of the Shirindareh River Basin, Iran. In Proceedings of the International Scientific Conference: Challenges in Modern Agricultural Production, Skopje, Macedonia, 11 December 2014.

55. Kavian, A.; Mohammadi, M.; Gholami, L.; Rodrigo-Comino, J. Assessment of the Spatiotemporal Effects of Land Use Changes on Runoff and Nitrate Loads in the Talar River. Water 2018, 10, 445. [CrossRef]

56. Khaleghi, M.R. The influence of deforestation and anthropogenic activities on runoff generation. J. For. Sci. 2017, 63, $245-253$.

57. Moeini, A.; Zarandi, N.K.; Pazira, E.; Badiollahi, Y. The relationship between drainage density and soil erosion rate: A study of five watersheds in Ardebil Province, Iran. WIT Trans. Ecol. Environ. 2015, 197, 129-138.

58. Bolleli, T.M.; Lense, G.H.E.; Santana, D.B.; Moreira, R.S.; Sestras, P.; Spalevic, V.; Mincato, R.L. Estimates of soil losses in watershed under tropical of altitude climate in Brazil. Agric. For. 2020, 66, 73-88.

59. Myronidis, D.; Arabatzis, G. Evaluation of Greek Post-Fire Erosion Mitigation Policy through Spatial Analysis. Pol. J. Environ. Stud. 2009, 18, 865-872.

60. Khoi, D.N.; Suetsugi, T. Impact of climate and land-use changes on hydrological processes and sediment yield-a case study of the Be River catchment, Vietnam. Hydrol. Sci. J. 2014, 59, 1095-1108. [CrossRef]

61. Kigira, F.K.; Gathenya, J.M.; Home, P.G. Modeling the Influence of Land Use/Land Cover changes on sediment yield and hydrology in Thika River catchment Kenya, using SWAT Model. In Proceedings of the 2007 JKUAT Scientific, Technological and Industrialisation Conference, Juja, Kenya, 25-26 October 2007.

62. Myronidis, D.; Ioannou, K.; Sapountzis, S.; Fotakis, D. Development of a sustainable plan to combat erosion for an island of the Mediterranean region. Fresenius Environ. Bull. 2010, 19, 1694-1702.

63. Dragicevic, N.; Karleusa, B.; Ozanic, N. Modification of erosion potential method using climate and land cover parameters. Nat. Hazards Risk 2018, 9, 1085-1105. [CrossRef]

64. Gocić, M.; Dragićević, S.; Radivojević, A.; Martić Bursać, N.; Stričević, L.; Đorđević, M. Changes in Soil Erosion Intensity Caused by Land Use and Demographic Changes in the Jablanica River Basin, Serbia. Agriculture 2020, 10, 345. [CrossRef]

65. Kostadinov, S.; Braunović, S.; Dragićević, S.; Zlatić, M.; Dragović, N.; Rakonjac, N. Effects of Erosion Control Works: Case Study-Grdelica Gorge, the South Morava River (Serbia). Water 2018, 10, 1094. [CrossRef]

66. Rodrigo-Comino, J.; Keesstra, S.; Cerdà, A. Soil Erosion as an Environmental Concern in Vineyards: The Case Study of Celler del Roure, Eastern Spain, by Means of Rainfall Simulation Experiments. Beverages 2018, 4, 31. [CrossRef]

67. Rodrigo-Comino, J.; Taguas, E.; Seeger, M.; Ries, J.B. Quantification of soil and water losses in an extensive olive orchard catchment in Southern Spain. J. Hydrol. 2018, 556, 749-758. [CrossRef]

68. Feng, T.; Wei, W.; Chen, L.; Rodrigo-Comino, J.; Die, C.; Feng, X.; Ren, K.; Brevik, E.C.; Yu, Y. Assessment of the impact of different vegetation patterns on soil erosion processes on semiarid loess slopes. Earth Surf. Process. Landf. 2018, 43, 1860-1870. [CrossRef]

69. Mohammadi, M.; Khaledi Darvishan, A.; Spalevic, V. Application of IntErO Model to Investigate the Effects of Land Use Changes on Soil Erosion and Sediment Yield in Talar Watershed, Northern Iran. In Book of Abstracts of the Green Room Sessions, Proceedings of the 2018 International GEA (Geo Eco-Eco Agro) Conference, Podgorica, Montenegro, 1-3 November 2018; Spalevic, V., Ed.; Faculty of Philosophy, University of Montenegro: Podgorica, Montenegro, 2018; p. 162. 